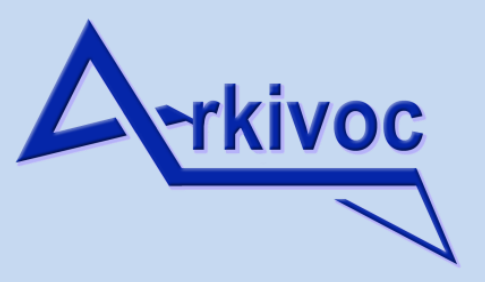

Free to Authors and Readers
A Platinum Open Access Journal for Organic Chemistry

DOAJ Seal

Arkivoc 2022, part iv, 46-57

\title{
Synthesis of phenazine-2,8-dicarboxylates
}

\author{
Grace E. O. Constable, ${ }^{\text {a Jane Jung, }}{ }^{\text {a }}$ Roger W. Read, ${ }^{a}$ Laurence P. G. Wakelin, ${ }^{a}$ Mohan M. Bhadbhade ${ }^{b}$ and \\ Luke Hunter*a \\ a School of Chemistry, University of New South Wales (UNSW), Sydney 2052, Australia \\ ${ }^{b}$ Mark Wainwright Analytical Centre, University of New South Wales (UNSW), Sydney 2052, Australia \\ Email: I.hunter@unsw.edu.au
}

Received 08-16-2021

Accepted Manuscript 11-16-2021

Published on line $12-10-2021$

\section{Abstract}

Phenazine is a tricyclic heteroarene that forms the core of diverse functional molecules including DNA intercalators. However, 2,8-disubstituted phenazines are rare, and this potentially limits the medicinal development of this class of heterocycles. Here we describe the synthesis of two new members of this compound class (i.e. dimethyl phenazine-2,8-dicarboxylate and the corresponding diacid), following a synthetic route that involved inter- and intramolecular Buchwald-Hartwig $\mathrm{N}$-arylations. We also detail a simple NMR-based method for proving the 2,8-disubstitution pattern, in order to counterbalance suspected structural misassignments elsewhere in the peer-reviewed and patent literature.

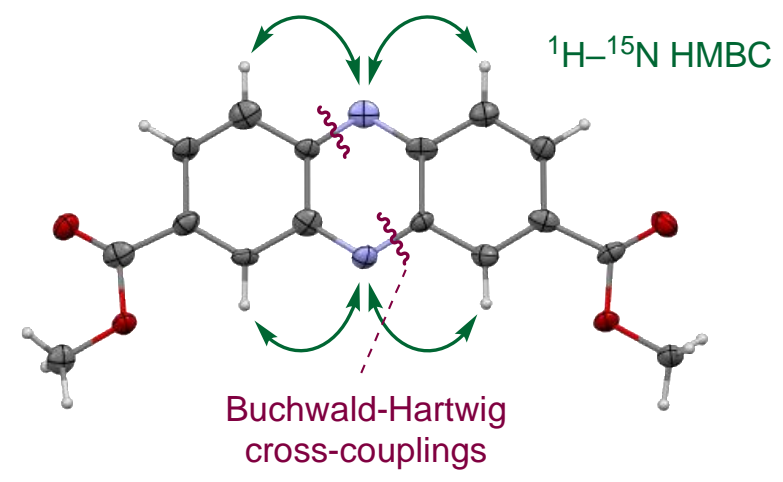

Keywords: Cross-coupling, nitrogen heterocycles, polycyclic aromatic hydrocarbons, phenazines, NMR spectroscopy 


\section{Introduction}

Phenazine is a tricyclic heteroarene that forms the core of diverse functional molecules including biochemical stains (e.g. 1, Figure 1), ${ }^{1}$ molecular switches (2), ${ }^{2}$ energy storage device components (3), ${ }^{3}$ and anti-cancer chemotherapeutic agents (e.g. 4). ${ }^{4}$ Despite the considerable structural diversity of substituted phenazines that can be found in the literature, ${ }^{5,6}$ preparations of exclusively 2,8-disubstituted phenazines bearing carbonbased substituents remain surprisingly rare, ${ }^{7-10}$ with many appearances stemming from Murdock's preparation of 2,8-dimethylphenazine.,11-16 Indeed, 2,8-disubstituted phenazines are even rarer than a cursory examination of the literature might suggest, because there have been occasional structural ambiguities or misassignments where 2,7-disubstituted phenazines may have been misreported as 2,8disubstituted phenazines. ${ }^{17-22}$ The scarcity of genuine 2,8-disubstituted phenazines in the literature with accompanying spectroscopic proof might suggest that these seemingly simple structures pose an unexpected synthetic challenge. This lack of synthetic availability might have limited the development of applications of these molecules.<smiles>C[N+]=c1ccc2nc3cc(C)c(N)cc3[nH]c-2c1</smiles>

1<smiles>O=C(NCCNCCNCCNC(=O)c1cccc2nc3ccccc3nc12)c1cccc2nc3ccccc3nc12</smiles>

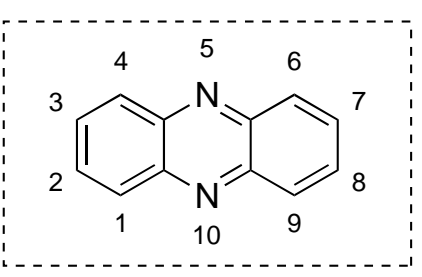<smiles>CCNC(=O)c1cccc2nc3c(C(N)=O)cccc3nc12</smiles>
$\mathrm{RHN}$<smiles>[R]Nc1ccc2nc3cc(N)ccc3nc2c1</smiles><smiles>[R]OC(=O)c1ccc2nc3ccc(C(=O)OCc4ccccc4)cc3nc2c1</smiles>

This work: $5 \quad \mathrm{R}=\mathrm{Me}$ $6 \mathrm{R}=\mathrm{H}$

Figure 1. Literature examples of substituted phenazines (1-4) and novel targets of this work $(\mathbf{5 , 6})$.

Recently, as part of a medicinal chemistry project focusing on DNA intercalators we desired to secure phenazine-2,8-dicarboxylates 5 and 6 (Figure 1). We therefore sought to identify, and describe herein, a reliable and regioselective method for accessing phenazine-2,8-dicarboxylates. We also describe a simple NMR-based method for distinguishing 2,8-from 2,7-disubstituted phenazines, to hopefully forestall any future structural misassignments. 


\section{Results and Discussion}

We considered several potential synthetic strategies at the outset of this work (Scheme 1). Murdock's reductive cyclization approach (Scheme 1a) is known to successfully afford 2,8-dimethyl phenazine, but only a limited substrate scope for this process has been reported. ${ }^{7}$ A double cross-coupling approach, such as that developed by Laha, ${ }^{23}$ is another validated option (Scheme 1b), but this method suffers from a lack of regioselectivity. We therefore decided to focus on two further approaches which offered the possibility of delivering our target compounds with appropriate regiocontrol and functional group tolerance. The first of these is a reductive cyclization approach based on the work of Holliman ${ }^{24,25}$ (Scheme 1c); and the second is a stepwise cross-coupling approach loosely based on the work of Emoto ${ }^{26}$ (Scheme 1d). The latter two approaches (Scheme 1c-d) have previously been employed to generate a variety of substituted phenazines, but never with the 2,8-disubstitution pattern.<smiles>Cc1ccc(Nc2ccc(C)cc2[N+](=O)[O-])c([N+](=O)[O-])c1</smiles>

7

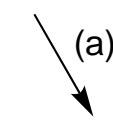<smiles>N#Cc1ccc(Cl)c(Cl)c1</smiles>

8<smiles>COc1ccc(N)c(N)c1</smiles>

(a)

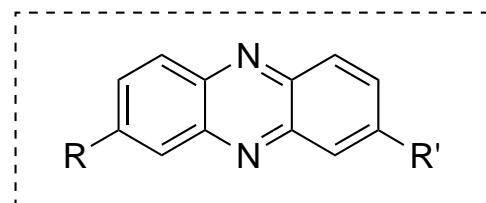

(c)

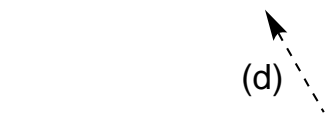<smiles>O=C(O)c1cccc(Nc2cc(C(=O)O)ccc2[N+](=O)[O-])c1</smiles>

10<smiles>COC(=O)c1ccc(Br)c([N+](=O)[O-])c1</smiles>

11
9

(b)

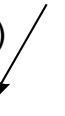

$\zeta$ previous

work<smiles>CC(=O)c1ccc(N)c(Br)c1</smiles>

12

Scheme 1. Potential strategies for synthesizing 2,8-disubstituted phenazines. (a) Murdock's reductive cyclization approach; (b) Laha's double cross-coupling approach; (c) this work, based on Holliman's reductive cyclization approach; (d) this work, based on Emoto's cross-coupling approach.

We investigated Holliman's reductive cyclization approach first (Scheme 2). An intramolecular BuchwaldHartwig cross-coupling reaction between aryl bromide 13 and aniline 14 successfully delivered the diarylamine 15, which upon hydrolysis gave the diacid 10. However, when diacid $\mathbf{1 0}$ was exposed to Holliman's reductive cyclization conditions, a complex mixture of products was formed, and separation of the mixture indicated that no cyclized product had formed. Previous explorations of the substrate scope of this type of cyclization reaction have indicated that while the reaction is robust to substituent variation on the nitrobenzene ring, substituent variation on the alternate ring can influence reactivity towards cyclization. ${ }^{24}$ We speculated that in our system, cyclization was too slow and could therefore have been outcompeted by alternative pathways 
such as over-reduction of the nitro group. We briefly explored a strategy that involved installing the bridging amine para to the carboxylate groups first (not shown); however, cyclization attempts yielded similar results.

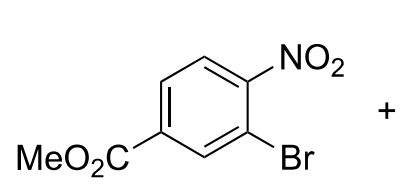

13

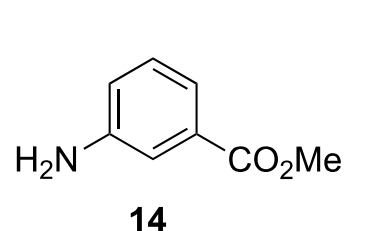

14

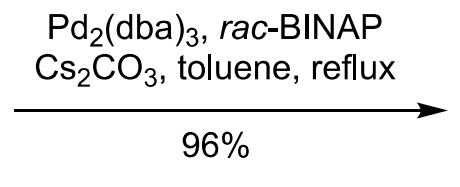

(<smiles>CC(=O)c1cccc(Nc2cc(C(C)=O)ccc2[N+](=O)[O-])c1</smiles>

15<smiles>[R]c1cc([R])c2nc3ccc(C(=O)O)cc3nc2c1</smiles>

$6 \quad \mathrm{R}^{1}=\mathrm{H} ; \mathrm{R}^{2}=\mathrm{CO}_{2} \mathrm{H}$ $16 \mathrm{R}^{1}=\mathrm{CO}_{2} \mathrm{H} ; \mathrm{R}^{2}=\mathrm{H}$

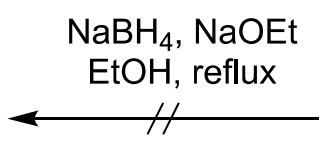<smiles>O=C(O)c1cccc(Nc2cc(C(=O)O)ccc2[N+](=O)[O-])c1</smiles>

10

Scheme 2. Attempted synthesis of phenazine-2,8-dicarboxylates via Holliman's reductive cyclization strategy.

Accordingly, we turned our attention to the strategy based on Emoto's stepwise cross-coupling approach (Scheme 3). Bromonitrobenzoate 11 and bromoaniline 12 underwent an intermolecular Buchwald-Hartwig Narylation, which delivered the diarylamine 17 in 78\% yield despite the possible competitive homocoupling of bromoaniline 12, which was not observed. The next task was to selectively reduce the nitro group of 17 to an aniline while avoiding dehalogenation. Reduction attempts using $\mathrm{Pd} / \mathrm{C}$ and hydrazine-hydrate as an in situ hydrogen source resulted in accompanying dehalogenation; however, iron powder ( -325 mesh) in the presence of hydrochloric acid successfully furnished the desired product (18) in good yield. A number of conditions were important in order to effectively mix the heterogenous reaction mixture, manage the use of ferromagnetic iron powder and avoid degradation of the product. These included vigorous stirring, moderate reaction scales $(\sim 1 \mathrm{~g})$, the use of fine iron powder and short reaction times. The final step in the synthesis of dimethyl phenazine-2,8-dicarboxylate (5) involved an intramolecular Buchwald-Hartwig $\mathrm{N}$-arylation and concurrent oxidation of the piperazine ring to form the phenazine core, which proceeded smoothly in good yield (Scheme 3). X-ray crystallographic analysis confirmed the assigned structure of the 2,8-diester (5), and a detailed discussion of the crystal structure and packing is supplied in the Supplementary Material. The bismethyl ester 5 was also hydrolyzed to the corresponding diacid 6, thereby furnishing another 2,8-disubstituted phenazine with versatile synthetic handles suitable for future elaboration. As an example of such elaborations, diacid 6 was coupled with $N^{1}, N^{1}$-dimethylethylenediamine to furnish diamide 19. 
<smiles>COC(=O)c1ccc(Nc2ccc(C(=O)OC)cc2[N+](=O)[O-])c([N+](=O)[O-])c1</smiles><smiles>[R]c1ccc2nc3ccc([R])cc3nc2c1</smiles>

$\mathrm{Cs}_{2} \mathrm{CO}_{3}$, toluene, reflux

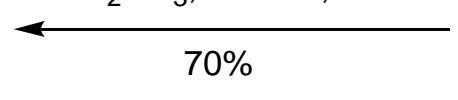
$5 \quad \mathrm{R}=\mathrm{CO}_{2} \mathrm{Me}$
(a) $90 \%$
$6 \mathrm{R}=\mathrm{CO}_{2} \mathrm{H}$
$19 \mathrm{R}=\mathrm{CONHCH}_{2} \mathrm{CH}_{2} \mathrm{NMe}_{2}$
(b) $60 \%$

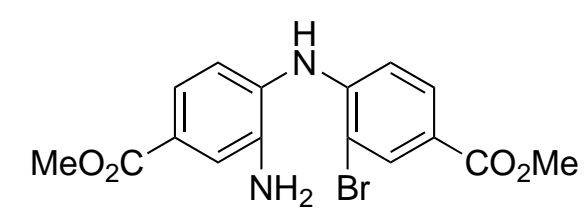

18

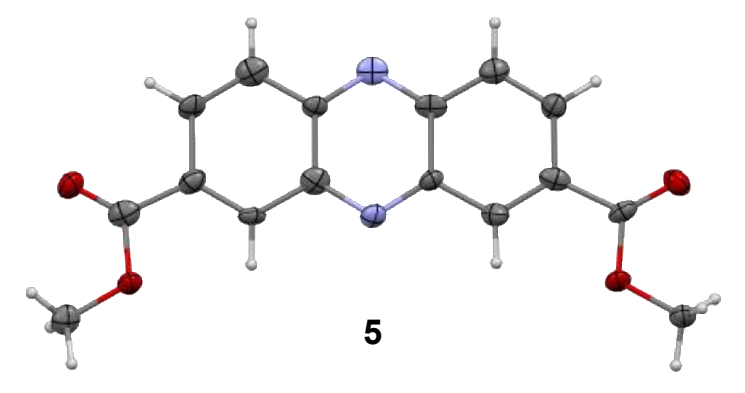

Scheme 3. Successful synthesis of phenazine-2,8-dicarboxylates $(5,6,19)$ via a successive cross-coupling strategy. (a) $\mathrm{H}_{2} \mathrm{O} / \mathrm{MeOH}, \mathrm{KOH}, 80^{\circ} \mathrm{C}$; (b) 1 . CDI, DMF, $50{ }^{\circ} \mathrm{C}$; 2. $N^{1}, N^{1}$-dimethylethylenediamine, DMF. The crystal structure is depicted with $50 \%$ probability ellipsoids.

Although there is no ambiguity about the structures of compounds 5, 6 and 19, we wish to describe a simple and broadly applicable spectroscopic method to distinguish the 2,8- from the 2,7-phenazine disubstitution pattern. ${ }^{1} \mathrm{H}$ and ${ }^{13} \mathrm{C}$ NMR-based methods are of limited utility for this purpose, because the 2,8and 2,7-disubstituted phenazines both contain analogous units of symmetry and there are no ${ }^{3} J_{\mathrm{CH}}$ throughbond couplings that extend between the nitrogen-separated units (Figure 2a). In contrast, ${ }^{15} \mathrm{NNMR}$ spectroscopy reduces the problem to a trivial exercise. The ${ }^{1} \mathrm{H}^{15} \mathrm{~N} \mathrm{HMBC}$ plot of 5 (Figure $2 \mathrm{~b}$ ) reveals that there are two nitrogen environments; this is consistent with structure $\mathbf{5}$ and inconsistent with structure $\mathbf{2 0}$ (Figure 2c). Also notable in the ${ }^{1} \mathrm{H}-{ }^{15} \mathrm{~N}$ HMBC plot of 5 is that each nitrogen atom correlates with just one proton environment; again, this is consistent with structure $\mathbf{5}$ and inconsistent with structure 20. This simple analysis should also be more broadly capable of distinguishing 2,8-from 2,7-disubstituted phenazines even if the two substituents were different and units of symmetry were not equivalent: for any 2,8-disubstituted phenazine, $\mathrm{N}^{5}$ should correlate exclusively with wide doublets (green) and $\mathrm{N}^{10}$ should correlate exclusively with narrow doublets (red); whereas for any 2,7-disubstituted phenazine, $\mathrm{N}^{5}$ and $\mathrm{N}^{10}$ should each couple to one wide and one narrow doublet. 
a) ${ }^{1} \mathrm{H}-\mathrm{NMR}$ multiplicities and unit of symmetry for $\mathbf{5}$ and $\mathbf{2 0}$

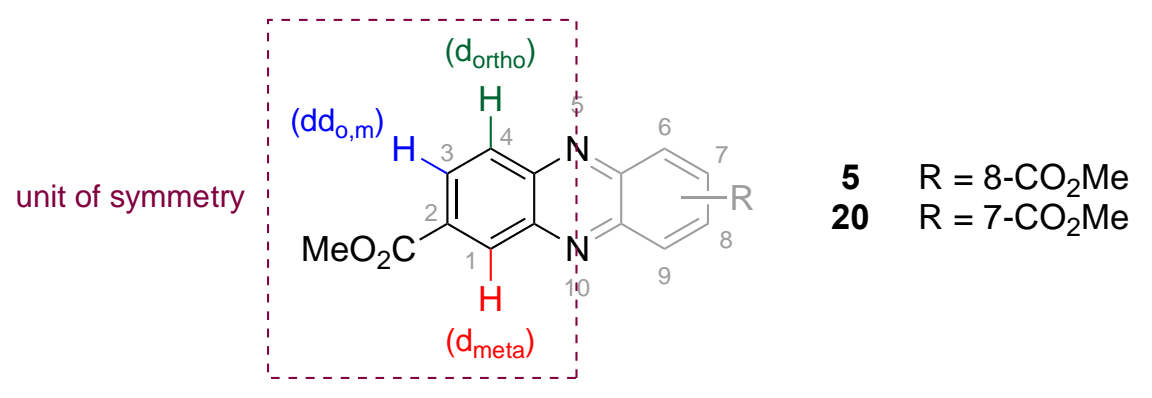

b) Observed ${ }^{3} \mathrm{~J}_{\mathrm{NH}}$ correlations for $5:{ }^{1} \mathrm{H}-{ }^{15} \mathrm{~N} \mathrm{HMBC}$

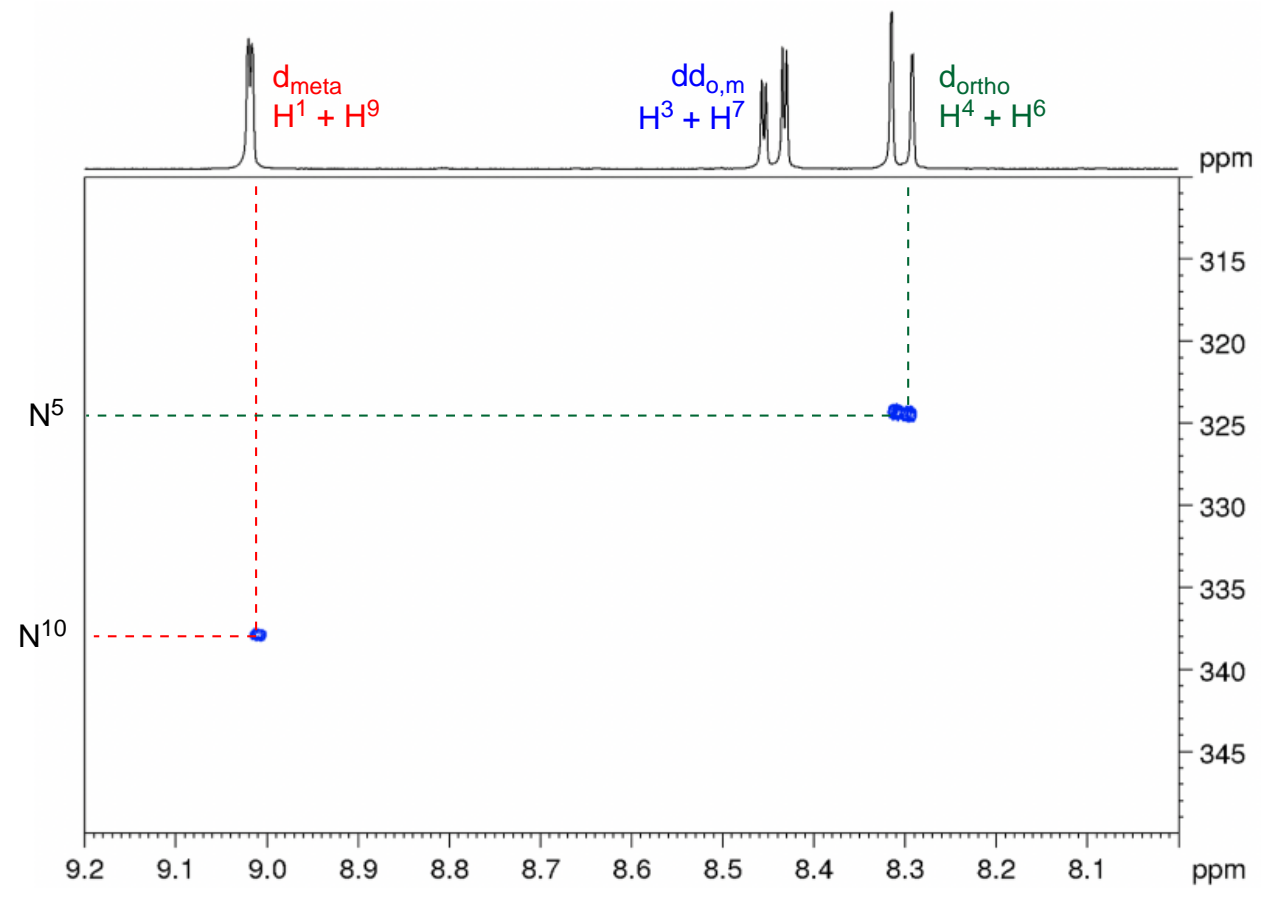

c) Expected ${ }^{3} \mathrm{~J}_{\mathrm{NH}}$ correlations for $\mathbf{5}$ and $\mathbf{2 0}$

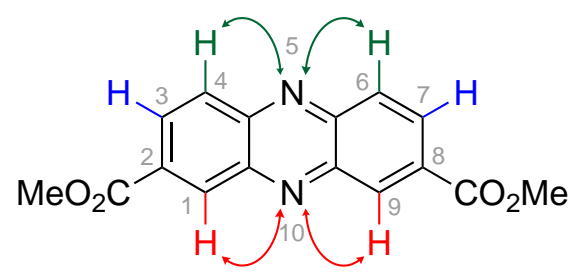

5

$\checkmark$ observed

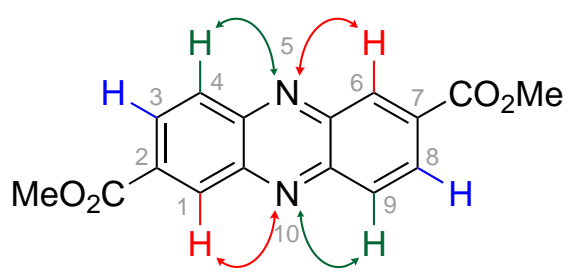

20

not observed

Figure 2. Structural proof of 2,8-disubstituted phenazines: (a) Expected multiplicities of aromatic peaks in ${ }^{1} \mathrm{H}$ NMR spectra; (b) ${ }^{1} \mathrm{H}-{ }^{15} \mathrm{~N}$ HMBC NMR plot for the isolated 2,8-isomer 5; (c) ${ }^{3} J_{\mathrm{NH}}$ correlations expected for dimethyl phenazine-2,8- and -2,7-dicarboxylate (5 and 20). 


\section{Conclusions}

We have described the synthesis of phenazine-2,8-dicarboxylic acid (6), its bis-methyl ester (5) and a representative diamide (19) through a modified version of Emoto's successive palladium-catalyzed N-arylation approach. We have also highlighted the ease with which ${ }^{15} \mathrm{~N}$ NMR analysis can be employed to specifically identify 2,8-disubstituted phenazines, which have previously been confused with the 2,7-disubstitution pattern. The target molecules produced in this work constitute a rare substitution pattern for the phenazine class, and they pave the way for the expanded utility of these chromophores through novel decorations and applications.

\section{Experimental Section}

General. Unless otherwise stated, reagents and solvents were purchased from commercial suppliers and used without further purification. Iron powder was purchased from Sigma-Aldrich (-325 mesh, 97\% purity, catalogue number 209309). The preparations of starting materials 11-14 are detailed in the Supplementary Material. When used as reaction solvents, toluene, dichloromethane and DMF were obtained from a solvent purification system and further dried over $4 \AA$ molecular sieves. Unless otherwise stated, reactions were performed under an atmosphere of nitrogen, and moisture-sensitive reactions in oven-dried glassware. Reactions were monitored by thin layer chromatography (TLC) where appropriate, using Merck aluminumbacked $60 \mathrm{~F}_{254} 0.2 \mathrm{~mm}$ silica plates. Plates were visualized by UV light $(254 \mathrm{~nm})$ and/or ninhydrin or potassium permanganate stains with heating. Purification by flash column chromatography was performed manually using Davisil 40-63 mesh silica gel. NMR spectra were obtained using Bruker Avance III instruments at 300, 400 and $600 \mathrm{MHz}$ and $298 \mathrm{~K}$, and calibrated using residual solvent signals as internal references. ${ }^{27}$ Molecular connectivities were assigned using 2D NMR experiments $\left({ }^{1} \mathrm{H}-{ }^{13} \mathrm{C} \mathrm{HSQC},{ }^{1} \mathrm{H}-{ }^{13} \mathrm{C} \mathrm{HMBC},{ }^{1} \mathrm{H}-{ }^{15} \mathrm{~N} \mathrm{HMBC}\right.$ and ${ }^{1} \mathrm{H}-{ }^{1} \mathrm{H}$ COSY) where possible, and by comparison of coupling constants. Chemical shifts are recorded in ppm. Multiplicities are designated as: $s=$ singlet; $b r s=$ broad singlet; $d=$ doublet; $d d=$ doublet of doublets; app $\mathrm{dt}=$ apparent doublet of triplets; $\mathrm{m}=$ multiplet. IR spectra were recorded on neat samples using an Agilent Technologies Cary 630 FTIR spectrometer with ATR attachment, and spectra were processed using MicroLab FTIR processing software. Characteristic peaks are reported and assigned based on reported ranges. ${ }^{28}$

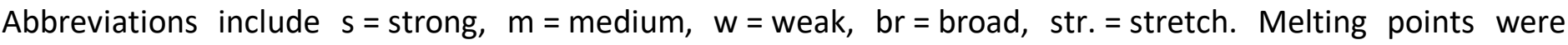
measured using an OptiMelt MPA100 automated melting point apparatus (Stanford Research Systems). HRMS results were recorded at the Bioanalytical Mass Spectrometry Facility (BMSF) at UNSW Sydney using an Orbitrap LTQ XL ion trap MS in positive ion mode with an electrospray (ESI) ion source. Methods detailed are of selected replicates of the procedure, and yields (mol\%) refer to isolated products for that replicate.

X-ray crystallography (Compound 5). Deposition Number 2058991 contains the supplementary crystallographic data for this paper. These data are provided free of charge by the joint Cambridge Crystallographic Data Centre and Fachinformationzentrum Karlsruhe Access Structures service www.ccdc.cam.ac.uk/structures. Further experimental details and discussion of the crystal packing of compound $\mathbf{5}$ are supplied in the Supplementary Material.

\section{Synthetic procedures}

Dimethyl phenazine-2,8-dicarboxylate (5). 18 (58.0 mg, $153 \mu \mathrm{mol}), \mathrm{Pd}_{2}(\mathrm{dba})_{3}(23.0 \mathrm{mg}, 25.2 \mu \mathrm{mol})$, rac-BINAP $(25.0 \mathrm{mg}, 40.3 \mu \mathrm{mol})$, and $\mathrm{Cs}_{2} \mathrm{CO}_{3}(246 \mathrm{mg}, 756 \mu \mathrm{mol})$ were suspended in dry toluene $(6 \mathrm{~mL})$ and heated to 
reflux for $2 \mathrm{~h}$, whereupon TLC indicated the consumption of the starting material. The reaction mixture was cooled to r.t., diluted with EtOAc $(20 \mathrm{~mL})$ and water $(15 \mathrm{~mL})$ added. $\mathrm{HCl}(2 \mathrm{M})$ was added to achieve $\mathrm{pH}$. The biphasic mixture was filtered to remove a black residue, which was washed with EtOAc (10 $\mathrm{mL})$. The phases of the filtrate were separated, and the aqueous phase extracted with EtOAc $(3 \times 30 \mathrm{~mL})$. The combined organic extracts were washed with brine $(20 \mathrm{~mL})$, dried $\left(\mathrm{MgSO}_{4}\right)$, filtered, and the filtrate concentrated under reduced pressure to afford a black and yellow crude solid. Purification of this material by flash chromatography (25$50 \%$ EtOAc in hexane) afforded the title compound as a yellow crystalline solid (29.6 mg, 65\%); $\mathrm{Rf} 0.31$ (30\% EtOAc in hexane); $\mathrm{mp} 204-206{ }^{\circ} \mathrm{C}$ (from EtOAc, yellow plates and needles); IR (neat) $v_{\max } 1710$ (s, $\mathrm{C}=\mathrm{O}$ str.), 1446 (m), 1266 (s) cm ${ }^{-1} ;{ }^{1} \mathrm{H}$ NMR (400 MHz, CDCl 3 ) $\delta 9.02$ (dd, J 0.4, $1.8 \mathrm{~Hz}, 2 \mathrm{H}, \mathrm{H}-1$ and H-9), 8.44 (dd, J 1.8, 9.1 Hz, 2H, H-3 and $\mathrm{H}-7$ ), $8.30(\mathrm{dd}, J 0.4,9.1 \mathrm{~Hz}, 2 \mathrm{H}, \mathrm{H}-4$ and $\mathrm{H}-6), 4.06\left(\mathrm{~s}, 6 \mathrm{H}, 2-\mathrm{CO}_{2} \mathrm{CH}_{3}\right.$ and 8$\left.-\mathrm{CO}_{2} \mathrm{CH}_{3}\right) ;{ }^{13} \mathrm{C}\left\{{ }^{1} \mathrm{H}\right\}$ NMR (101 MHz, CDCl 3$) \delta 166.1\left(2-\mathrm{CO}_{2} \mathrm{CH}_{3}\right.$ and 8- $\mathrm{CO}_{2} \mathrm{CH}_{3}$ ), 145.6 (C4a and C5a), 143.4 (C9a and $\mathrm{C} 10 \mathrm{a}$ ), 133.3 (C1 and C9), 132.2 (C2 and C8), 130.5 (C3 and C7), 130.2 (C4 and C6), $53.0\left(2-\mathrm{CO}_{2} \mathrm{CH}_{3}\right.$ and 8- $\left.\mathrm{CO}_{2} \mathrm{CH}_{3}\right) ; \mathrm{HRMS}(\mathrm{ESI},+\mathrm{ve}) \mathrm{C}_{16} \mathrm{H}_{13} \mathrm{~N}_{2} \mathrm{O}_{4}{ }^{+}[\mathrm{M}+\mathrm{H}]^{+}$requires $\mathrm{m} / \mathrm{z} 297.0870$, found 297.0868 .

Phenazine-2,8-dicarboxylic acid (6). 5 (28.0 mg, $94.5 \mu \mathrm{mol})$, was added to a solution of $\mathrm{KOH}$ in $3: 1 \mathrm{MeOH}: \mathrm{H}_{2} \mathrm{O}$ $(0.37 \mathrm{M}, 3 \mathrm{~mL})$. The suspension was heated to $80^{\circ} \mathrm{C}$ for $4 \mathrm{~h}$ under an atmosphere of air, and the presence of a yellow solid persisted. The suspension was cooled to r.t. and $\mathrm{HCl}(2 \mathrm{M})$ was added until $\mathrm{pH} 2$ was reached; more yellow precipitate appeared to form. The solid was collected by vacuum filtration and washed with $\mathrm{HCl}$ $(0.2 \mathrm{M}, 3 \mathrm{~mL})$ and water $(3 \mathrm{~mL})$, and dried under vacuum. Further azeotroping of water with $\mathrm{MeOH}$ and EtOAc afforded the title compound as a yellow solid $(23 \mathrm{mg}, 90 \%) ; \mathrm{mp}>340^{\circ} \mathrm{C}$ (dec); IR (neat) $v_{\max } 2809$ (br, O-H str.), 1683 (s, C=O str.), 1407 (m), 1274 (s) cm ${ }^{-1} ;{ }^{1} \mathrm{H}$ NMR (400 MHz, DMSO-d $) \delta 8.82$ (dd, J 1.7, $0.8 \mathrm{~Hz}, 2 \mathrm{H}, \mathrm{H}-1$ and $\mathrm{H}-9), 8.40(\mathrm{dd}, J 9.1,1.7 \mathrm{~Hz}, 2 \mathrm{H}, \mathrm{H}-3$ and $\mathrm{H}-7), 8.37(\mathrm{dd}, J 9.1,0.8 \mathrm{~Hz}, 2 \mathrm{H}, \mathrm{H}-4$ and $\mathrm{H}-6) ;{ }^{13} \mathrm{C}\left\{{ }^{1} \mathrm{H}\right\} \mathrm{NMR}$ $\left(101 \mathrm{MHz}, \mathrm{DMSO}-d_{6}\right) \delta 166.4\left(2-\mathrm{CO}_{2} \mathrm{H}\right.$ and $8-\mathrm{CO}_{2} \mathrm{H}$ ), 144.8 (C4a and $\left.\mathrm{C} 5 \mathrm{a}\right), 142.7$ (C9a and C10a), 133.2 (C2 and C8), 132.0 (C1 and C9), 130.6 (C3 and C7), 130.0 (C4 and C6); HRMS (ESI, +ve) $\mathrm{C}_{14} \mathrm{H}_{9} \mathrm{~N}_{2} \mathrm{O}_{4}{ }^{+}[\mathrm{M}+\mathrm{H}]^{+}$requires $\mathrm{m} / \mathrm{z}$ 269.0557, found 269.0557.

3-((3-Carboxyphenyl)amino)-4-nitrobenzoic acid (10). To a solution of 15 (250 mg, $757 \mathrm{mmol})$ in $\mathrm{MeOH}(6 \mathrm{~mL})$ was added a solution of $\mathrm{KOH}(127 \mathrm{mg}, 2.27 \mathrm{mmol})$ in water $(2 \mathrm{~mL})$. The resultant solution was stirred for $24 \mathrm{~h}$ and monitored by TLC for consumption of the starting material. After $24 \mathrm{~h}$, the reaction mixture was heated to $80^{\circ} \mathrm{C}$ for $20 \mathrm{~h}$, then cooled to r.t.. $\mathrm{HCl}(2 \mathrm{M})$ was added to achieve $\mathrm{pH} 2$, and the resultant red precipitate was collected by vacuum filtration and washed with $\mathrm{HCl}(0.1 \mathrm{M}, \sim 3 \mathrm{~mL})$ and water $(\sim 3 \mathrm{~mL})$. Azeotroping of water was achieved with EtOH and EtOAc, affording the title compound as a red solid (224 mg, 98\%); IR (neat) $v_{\max }$ 3350 (w, N-H str.), 2849 (br, O-H str.), 1691 (s, C=O str.), 1419 (m), 1339 (w), 1306 (m), 1280 (s) cm ${ }^{-1} ;{ }^{1} \mathrm{H} \mathrm{NMR}$ (400 MHz, DMSO) $\delta 9.42(\mathrm{~s}, 1 \mathrm{H}, \mathrm{NH}), 8.19(\mathrm{~d}, J 8.8 \mathrm{~Hz}, 1 \mathrm{H}, \mathrm{H}-5), 7.86-7.84(\mathrm{~m}, 1 \mathrm{H}, \mathrm{H}-2$ '), 7.76 (app dt, J 1.7, $\left.6.8 \mathrm{~Hz}, 1 \mathrm{H}, \mathrm{H}-4^{\prime}\right), 7.71(\mathrm{~d}, J 1.7 \mathrm{~Hz}, 1 \mathrm{H}, \mathrm{H}-2), 7.60-7.52\left(\mathrm{~m}, 2 \mathrm{H}, \mathrm{H}-5^{\prime}\right.$ and H-6'), $7.38(\mathrm{dd}, J 1.7,8.8 \mathrm{~Hz}, 1 \mathrm{H}$, $\mathrm{H}-6) ;{ }^{13} \mathrm{C}\left\{{ }^{1} \mathrm{H}\right\}$ NMR (100 MHz, DMSO) $\delta 166.8$ (3'-CO2H), 165.8 (1-CO2H), 141.0 (C3), 139.9 (C1'), 136.9 (C1), 136.5 (C4), 132.3 (C3'), 129.9 (C5'), 127.6 (C6'), 126.8 (C5), 125.5 (C4'), 124.0 (C2'), 118.41 (C6), 118.36 (C2); HRMS (ESI, +ve) $\mathrm{C}_{14} \mathrm{H}_{10} \mathrm{~N}_{2} \mathrm{O}_{6} \mathrm{Na}^{+}[\mathrm{M}+\mathrm{Na}]^{+}$requires $\mathrm{m} / \mathrm{z} 325.0431$, found 325.0418 .

Methyl 3-((3-(methoxycarbonyl)phenyl)amino)-4-nitrobenzoate (15). Methyl 3-bromo-4-nitrobenzoate (13, $200 \mathrm{mg}, 769 \mu \mathrm{mol})$, methyl 3-aminobenzoate (14, $140 \mathrm{mg}, 923 \mu \mathrm{mol}), \mathrm{Pd}_{2}(\mathrm{dba})_{3}(35 \mathrm{mg}, 38 \mu \mathrm{mol}), \operatorname{rac}-\mathrm{BINAP}$ (38 mg, $62 \mu \mathrm{mol}$ ) and $\mathrm{Cs}_{2} \mathrm{CO}_{3}(376 \mathrm{mg}, 1.15 \mathrm{mmol}$ ) were suspended in dry toluene $(8 \mathrm{~mL})$, and heated to reflux for $18 \mathrm{~h}$. The reaction mixture was cooled to r.t., diluted with EtOAc $(20 \mathrm{~mL})$ and water $(20 \mathrm{~mL})$ added. The biphasic mixture was filtered to remove a black residue, which was washed with EtOAc (10 $\mathrm{mL})$. The filtrate phases were separated, and organic phase washed with $\mathrm{HCl}(2 \mathrm{M}, 2 \times 20 \mathrm{~mL})$. The combined aqueous phases were extracted with EtOAc $(2 \times 20 \mathrm{~mL})$ and the organic extracts were combined, washed with brine $(20 \mathrm{~mL})$, dried $\left(\mathrm{MgSO}_{4}\right)$, filtered and the filtrate concentrated under reduced pressure to afford a red and black 
heterogenous residue. Purification by flash chromatography (15-50\% EtOAc in hexane) yielded the title compound as an orange solid (244 mg, 96\%); $R_{f} 0.36$ (30\% EtOAc in hexane); $\mathrm{mp}>173{ }^{\circ} \mathrm{C}$ (dec); IR (neat) $v_{\max }$

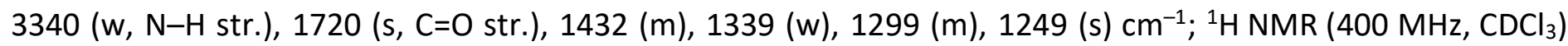
$\delta 9.45(\mathrm{br} \mathrm{s}, 1 \mathrm{H}, \mathrm{NH}), 8.27(\mathrm{~d}, J 8.9 \mathrm{~Hz}, 1 \mathrm{H}, \mathrm{H}-5), 7.96-7.92\left(\mathrm{~m}, 2 \mathrm{H}, \mathrm{H}-2^{\prime}\right.$ and H-6'), $7.87(\mathrm{~d}, J 1.7 \mathrm{~Hz}, 1 \mathrm{H}, \mathrm{H}-2)$, 7.55-7.47 (m, 2H, H-4' and $\left.\mathrm{H}-5^{\prime}\right), 7.41(\mathrm{dd}, J 1.7,8.9 \mathrm{~Hz}, 1 \mathrm{H}, \mathrm{H}-6), 3.94\left(\mathrm{~s}, 3 \mathrm{H}, 3{ }^{\prime}-\mathrm{CO}_{2} \mathrm{CH}_{3}\right), 3.88(\mathrm{~s}, 3 \mathrm{H}$, 1- $\left.\mathrm{CO}_{2} \mathrm{CH}_{3}\right) ;{ }^{13} \mathrm{C}\left\{{ }^{1} \mathrm{H}\right\}$ NMR (101 MHz, CDCl$) \delta 166.4\left(3^{\prime}-\mathrm{CO}_{2} \mathrm{CH}_{3}\right), 165.5\left(1-\underline{\mathrm{CO}_{2}} \mathrm{CH}_{3}\right), 142.2$ (C3), 138.9 (C1'), 136.5 (C1), 135.7 (C4), 132.3 (C3'), 130.2 (C5'), 128.5 (C4'), 127.2 (C5), 127.1 (C6'), 125.3 (C2'), 118.3 (C6), 118.0 (C2), $52.9\left(1-\mathrm{CO}_{2} \mathrm{CH}_{3}\right), 52.5\left(3^{\prime}-\mathrm{CO}_{2} \underline{\mathrm{CH}}_{3}\right) ; \mathrm{HRMS}(\mathrm{ESI},+\mathrm{ve}) \mathrm{C}_{16} \mathrm{H}_{14} \mathrm{~N}_{2} \mathrm{O}_{6} \mathrm{Na}^{+}[\mathrm{M}+\mathrm{Na}]^{+}$requires $\mathrm{m} / \mathrm{z} 353.0744$, found 353.0733.

Methyl 3-bromo-4-((4-(methoxycarbonyl)-2-nitrophenyl)amino)benzoate

(17). Methyl 4-bromo3-nitrobenzoate $(\mathbf{1 1}, 2.16 \mathrm{~g}, 8.32 \mathrm{mmol})$, methyl 4-amino-3-bromobenzoate $(\mathbf{1 2}, 1.92 \mathrm{~g}, 8.32 \mathrm{mmol})$, rac-BINAP $(827 \mathrm{mg}, 1.33 \mathrm{mmol})$, and $\mathrm{Cs}_{2} \mathrm{CO}_{3}(8.16 \mathrm{~g}, 25.0 \mathrm{mmol})$ were suspended in dry toluene $(90 \mathrm{~mL})$ and heated to reflux. $\mathrm{Pd}_{2}(\mathrm{dba})_{3}(764 \mathrm{mg}, 834 \mu \mathrm{mol})$ and further toluene $(10 \mathrm{~mL})$ were added, and the suspension stirred at reflux for $3.5 \mathrm{~h}$, before being cooled to r.t.. A yellow precipitate was observed to form within the already heterogenous mixture. The mixture was diluted with dichloromethane $(300 \mathrm{~mL})$ until the yellow precipitate dissolved, and the mixture filtered through a pad of celite to remove residual solid material. $\mathrm{HCl}(0.1 \mathrm{M}$, $200 \mathrm{~mL}$ ) was added to the filtrate, and the biphasic mixture separated. The aqueous phase was extracted with further dichloromethane $(2 \times 100 \mathrm{~mL})$, and the combined organic extracts were washed with brine $(50 \mathrm{~mL})$, dried $\left(\mathrm{MgSO}_{4}\right)$, filtered and the filtrate concentrated under reduced pressure. Iterative triturations from EtOAc afforded the title compound as a yellow-orange crystalline solid ( $2.47 \mathrm{~g}, 73 \%) ; \mathrm{R}_{\mathrm{f}} 0.27$ (30\% EtOAc in hexane);

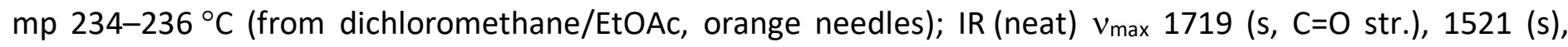
1431 (s), 1346 (m), 1298 (s), 1261 (s) cm $\left.{ }^{-1} ;{ }^{1} \mathrm{H} \mathrm{NMR} \mathrm{(400} \mathrm{MHz,} \mathrm{CDCl}\right)^{2} \delta 9.90$ (br s, 1H, NH), 8.93 (d, J 2.0 Hz, 1H, $\mathrm{H}_{-3}$ ), 8.37 (d, J $\left.1.9 \mathrm{~Hz}, 1 \mathrm{H}, \mathrm{H}-2\right), 8.09$ (dd, J 8.9, $\left.2.0 \mathrm{~Hz}, 1 \mathrm{H}, \mathrm{H}-5^{\prime}\right), 8.02$ (dd, J 8.4, 1.9 Hz, 1H, H-6), $7.53(\mathrm{~d}$, J $8.4 \mathrm{~Hz}, 1 \mathrm{H}, \mathrm{H}-5), 7.36(\mathrm{~d}, J 8.9 \mathrm{~Hz}, 1 \mathrm{H}, \mathrm{H}-6 \mathrm{\prime}), 3.95-3.93\left(\mathrm{~m}, 6 \mathrm{H}, 1-\mathrm{CO}_{2} \mathrm{CH}_{3}\right.$ and $\left.4{ }^{\prime}-\mathrm{CO}_{2} \mathrm{CH}_{3}\right) ;{ }^{13} \mathrm{C}\left\{{ }^{1} \mathrm{H}\right\} \mathrm{NMR}$ $\left(101 \mathrm{MHz}, \mathrm{CDCl}_{3}\right) \delta 165.2\left(1-\mathrm{CO}_{2} \mathrm{CH}_{3}\right), 165.1$ (4'- $\left.\mathrm{CO}_{2} \mathrm{CH}_{3}\right), 142.8$ (C1'), 141.1 (C4), 136.1 (C5'), 135.4 (C2), 134.6 (C2'), 129.8 (C6), 129.2 (C3'), 128.1 (C1), 122.1 (C5), 121.7 (C4') 117.7 (C3), 116.6 (C6'), 52.64 (1- $\mathrm{CO}_{2} \mathrm{CH}_{3}$ or 4'- $\left.\mathrm{CO}_{2} \underline{\mathrm{CH}_{3}}\right), 52.58\left(1-\mathrm{CO}_{2} \underline{\mathrm{CH}_{3}}\right.$ or $\left.4^{\prime}-\mathrm{CO}_{2} \underline{\mathrm{CH}_{3}}\right)$; HRMS (ESI, +ve) $\mathrm{C}_{16} \mathrm{H}_{14} \mathrm{O}_{6} \mathrm{~N}_{2} \mathrm{Br}^{+}[\mathrm{M}+\mathrm{H}]^{+}$requires $\mathrm{m} / \mathrm{z}$ 409.0030, 411.0009, found 409.0027, 411.0007.

Methyl 3-amino-4-((2-bromo-4-(methoxycarbonyl)phenyl)amino)-benzoate (18). $\mathrm{HCl}(2 \mathrm{M}, 4 \mathrm{~mL})$ and $\mathrm{MeOH}$ $(40 \mathrm{~mL})$ were combined and degassed with nitrogen before iron powder ( -325 mesh, $1.64 \mathrm{~g}, 29.3 \mathrm{mmol})$ and $17(1.00 \mathrm{~g}, 2.44 \mathrm{mmol})$ were added. The resultant heterogenous mixture was stirred vigorously and heated to reflux for $5.5 \mathrm{~h}$, whereupon TLC indicated the consumption of starting material. The black mixture was poured into dichloromethane $(150 \mathrm{~mL})$ and saturated $\mathrm{NaHCO}_{3}$ solution $(50 \mathrm{~mL})$ was added. The biphasic suspension was filtered through a wide funnel with filter paper, and the phases subsequently separated. The aqueous phase was extracted with further dichloromethane $(2 \times 50 \mathrm{~mL})$. Organic extracts were combined, washed with brine, and the aqueous layer re-extracted with further dichloromethane $(50 \mathrm{~mL})$. Combined organic extracts were dried $\left(\mathrm{MgSO}_{4}\right)$, filtered and the filtrate concentrated under reduced pressure. The resultant pale brown residue was purified by flash chromatography (40-60\% EtOAc in hexane) to give the title compound as a pink solid (768 mg, 83\%); $\mathrm{R}_{\mathrm{f}} 0.34$ (40\% EtOAc in hexane); $\mathrm{mp} 146-156{ }^{\circ} \mathrm{C}$ (from EtOAc, pink needles); IR (neat) $v_{\max }$ 3399 (m, NH str.) 3365 (w, NH str.) 3328 (w, NH str.), 1695 (s, C=O str.), 1429 (m), 1323 (m), 1275 (s), 1241 (s), 1033 (w) cm ${ }^{-1}$; ${ }^{1} \mathrm{H}$ NMR (400 MHz, DMSO-d $) \delta 8.04$ (d, J $\left.2.0 \mathrm{~Hz}, 1 \mathrm{H}, \mathrm{H}-3^{\prime}\right), 7.72$ (dd, J 8.6, 2.0 Hz, 1H, H-5'), 7.45 (d, J $1.9 \mathrm{~Hz}, 1 \mathrm{H}, \mathrm{H}-2$ ), 7.41 (s, 1H, NH), 7.19 (dd, J 8.2, $1.9 \mathrm{~Hz}, 1 \mathrm{H}, \mathrm{H}-6), 7.09$ (d, J $8.2 \mathrm{~Hz}, 1 \mathrm{H}, \mathrm{H}-5), 6.59$ (d, J $8.6 \mathrm{~Hz}, 1 \mathrm{H}, \mathrm{H}-6$ ') $5.22\left(\mathrm{~s}, 2 \mathrm{H}, \mathrm{NH}_{2}\right), 3.81\left(\mathrm{~s}, 3 \mathrm{H}, 1-\mathrm{CO}_{2} \mathrm{CH}_{3}\right), 3.79\left(\mathrm{~s}, 3 \mathrm{H}, 4{ }^{\prime}-\mathrm{CO}_{2} \mathrm{CH}_{3}\right) ;{ }^{13} \mathrm{C}\left\{{ }^{1} \mathrm{H}\right\} \mathrm{NMR}(101 \mathrm{MHz}$, DMSO-d $\left.d_{6}\right) 166.4\left(1-\mathrm{CO}_{2} \mathrm{CH}_{3}\right), 165.1\left(4^{\prime}-\mathrm{CO}_{2} \mathrm{CH}_{3}\right), 146.6$ (C1'), 143.2 (C3), 133.9 (C3'), 129.8 (C5'), 129.5 (C4), 
127.0 (C1), 125.1 (C5), 120.4 (C4'), 117.7 (C6), 116.3 (C2), 114.4 (C6'), 109.6 (C2'), 51.9 (2C, 1-CO ${ }_{2} \mathrm{CH}_{3}$ and 4'- $\left.\mathrm{CO}_{2} \underline{\mathrm{C}} \mathrm{H}_{3}\right) ; \mathrm{HRMS}(\mathrm{ESI},+v e) \mathrm{C}_{16} \mathrm{H}_{16} \mathrm{BrN}_{2} \mathrm{O}_{4}{ }^{+}[\mathrm{M}+\mathrm{H}]^{+}$requires $\mathrm{m} / \mathrm{z} 379.0288$, 381.0268, found 379.0281, 381.0258.

$\mathbf{N}^{2}, \boldsymbol{N}^{\mathbf{8}}$-Bis(2-(dimethylamino)ethyl)phenazine-2,8-dicarboxamide (19). To a stirring solution of 6 (100 mg, $0.373 \mathrm{mmol})$ in DMF $(8 \mathrm{~mL})$ at $50^{\circ} \mathrm{C}$ was added CDI (544 mg, $\left.3.35 \mathrm{mmol}\right)$. The resultant yellow suspension was stirred for $1 \mathrm{~h}$ at $50^{\circ} \mathrm{C}$ and was observed to nearly turn transparent before further yellow precipitate formed. After cooling to r.t., EtOAc $(1 \mathrm{~mL})$ was added and the precipitate collected by vacuum filtration and washed with EtOAc and hexane. Residual solvent was removed under reduced pressure, to yield a bisimidazolyl intermediate, phenazine-2,8-diylbis((1H-imidazol-1-yl)methanone), as a fluffy yellow solid (122 mg, 89\%). A portion of this material $(54 \mathrm{mg}, 0.15 \mathrm{mmol})$ was resuspended in DMF $(2 \mathrm{~mL})$, and $N^{1}, N^{1}-$ dimethylethylenediamine $(48 \mu \mathrm{L}, 0.44 \mathrm{mmol}$ ) added. The reaction mixture was stirred for $1 \mathrm{~h}$ at r.t., then placed under vacuum to reduce the volume by half. Diethyl ether $(2 \mathrm{~mL})$ was added and the resultant precipitate was collected by vacuum filtration (drawing excessive air or additional solvent over the solid was avoided) to yield the title compound as a powdery yellow solid (40 mg, 67\%); IR (neat) $v_{\max } 3296$ (w, N-H str.), 2938 (w, C-H str.), 2616 (w, C-H str.), 2760 (w, C-H str.), 1626 (s, C=O str.), 1535 (s), 1282 (m) cm ${ }^{-1} ;{ }^{1} \mathrm{H} \mathrm{NMR}$ (400 MHz, CD $\left.{ }_{3} \mathrm{OD}\right) \delta 8.77-8.74(\mathrm{~m}, 2 \mathrm{H}, \mathrm{H}-1$ and $\mathrm{H}-9), 8.37-8.29(\mathrm{~m}, 4 \mathrm{H}, \mathrm{H}-3, \mathrm{H}-7, \mathrm{H}-4$ and H-6), 3.65 (t, J $6.7 \mathrm{~Hz}$, $\left.4 \mathrm{H}, \mathrm{CH}_{2}-1^{\prime}\right), 2.67\left(\mathrm{t}, J 6.7 \mathrm{~Hz}, 4 \mathrm{H}, \mathrm{CH}_{2}-2{ }^{\prime}\right), 2.37\left(\mathrm{~s}, 12 \mathrm{H}, \mathrm{CH}_{3}\right) ;{ }^{13} \mathrm{C}\left\{{ }^{1} \mathrm{H}\right\} \mathrm{NMR}\left(101 \mathrm{MHz}, \mathrm{CD}_{3} \mathrm{OD}\right) \delta 168.6(\mathrm{C}=\mathrm{O})$, 145.8 (C4a), 144.6 (C9a), 138.0 (C2), 130.9 (C3), 130.8 (C4), 130.3 (C1), 59.2 (C2'), 45.6 (CH), 38.9 (C1'); HRMS (ESI, +ve) $\mathrm{C}_{22} \mathrm{H}_{29} \mathrm{~N}_{6} \mathrm{O}_{2}{ }^{+}[\mathrm{M}+\mathrm{H}]^{+}$requires $\mathrm{m} / \mathrm{z} 409.2347$, found 409.2346.

\section{Acknowledgements}

The authors thank Graham Ball and Donald Thomas for support in obtaining ${ }^{1} \mathrm{H}-{ }^{15} \mathrm{~N}$ NMR data. G.E.O.C. acknowledges financial support from the Australian Government's Research Training Program and the Westpac Scholars Trust.

\section{Supplementary Material}

Supplementary Material is provided online via the journal issue contents page and contains additional experimental details for the preparation of starting materials 11-14, additional NMR and X-ray crystallographic data, a discussion of the crystal packing of compound $\mathbf{5}$ and characterization data for isolated compounds.

\section{References}

1. Sabnis, R. W. Handbook of Biological Dyes and Stains; John Wiley \& Sons, Inc.: New Jersey, 2010; pp 249251, 324-326, 425-427.

2. Yin, J.; Khalilov, A. N.; Muthupandi, P.; Ladd, R.; Birman, V. B. J. Am. Chem. Soc. 2020, 142, 60-63. https://doi.org/10.1021/jacs.9b11160. 
3. Vitaku, E.; Gannett, C. N.; Carpenter, K. L.; Shen, L.; Abruña, H. D.; Dichtel, W. R. J. Am. Chem. Soc. 2020, $142,16-20$.

https://doi.org/10.1021/jacs.9b08147.

4. Cimmino, A.; Evidente, A.; Mathieu, V.; Andolfi, A.; Lefranc, F.; Kornienko, A.; Kiss, R. Nat. Prod. Rep. 2012, 29, 487-501.

https://doi.org/10.1039/c2np00079b.

5. Urleb, U.; Gobec, S. In Category 2, Hetarenes and Related Ring Systems; Yamamoto, Y.; Shinkai, I. Eds.; Thieme Verlagsgruppe: Stuttgart, 2004; Vol. 16, pp 913-943.

https://doi.org/10.1055/sos-SD-016-01123.

6. Chaudhary, A.; Khurana, J. M. Res. Chem. Intermed. 2018, 44, 1045-1083. https://doi.org/10.1007/s11164-017-3152-8.

7. Murdock, K. C.; Lin, Y.; Thomas, J. P.; Lang, S. A. J. Med. Chem. 1978, 21, 403-405. https://doi.org/10.1021/jm00202a020.

8. Gleiter, M. R.; Kanellakopulos, B.; Krieger, C.; Neugebauer, F. A. Liebigs Ann./Recl. 1997, 1997, 473-483. https://doi.org/10.1002/jlac.199719970307.

9. Lian, Y.; Hummel, J. R.; Bergman, R. G.; Ellman, J. A. J. Am. Chem. Soc. 2013, 135, 12548-12551. https://doi.org/10.1021/ja406131a.

10. Xiao, Y.; Wu, X.; Wang, H.; Sun, S.; Yu, J. T.; Cheng, J. Org. Lett. 2019, 21, 2565-2568. https://doi.org/10.1021/acs.orglett.9b00502.

11. Lorente, A.; Fernández-Saiz, M.; Herraiz, F.; Lehn, J. M.; Vigneron, J. P. Tetrahedron Lett. 1999, 40, 59015904.

https://doi.org/10.1016/S0040-4039(99)01126-0.

12. Granzhan, A.; Largy, E.; Saettel, N.; Teulade-Fichou, M. P. Chem. - Eur. J. 2010, 16, 878-889. https://doi.org/10.1002/chem.200901989.

13. Granzhan, A.; Monchaud, D.; Saettel, N.; Guédin, A.; Mergny, J. L.; Teulade-Fichou, M. P. J. Nucleic Acids 2010, 2010, Article ID 460561. https://doi.org/10.4061/2010/460561.

14. Naud-Martin, D.; Martin-Benlloch, X.; Poyer, F.; Mahuteau-Betzer, F.; Teulade-Fichou, M. P. Biotechnol. J. 2014, 9, 301-310.

https://doi.org/10.1002/biot.201300197.

15. Novotna, J.; Laguerre, A.; Granzhan, A.; Pirrotta, M.; Teulade-Fichou, M. P.; Monchaud, D. Org. Biomol. Chem. 2015, 13, 215-222. https://doi.org/10.1039/c4ob01846j.

16. Guyon, L.; Pirrotta, M.; Duskova, K.; Granzhan, A.; Teulade-Fichou, M. P.; Monchaud, D. Nucleic Acids Res. 2018, 46 (3), e16. https://doi.org/10.1093/nar/gkx1118.

17. Muppidi, A.; Doi, K.; Ramil, C. P.; Wang, H. G.; Lin, Q. Tetrahedron 2014, 70, 7740-7745. https://doi.org/10.1016/j.tet.2014.05.104.

18. Muppidi, A.; Zou, H.; Yang, P. Y.; Chao, E.; Sherwood, L.; Nunez, V.; Woods, A. K.; Schultz, P. G.; Lin, Q.; Shen, W. ACS Chem. Biol. 2016, 11, 324-328. https://doi.org/10.1021/acschembio.5b00787.

19. Lin, Q.; Muppidi, A.; Shen, W.; Zou, H.; Schultz, P.; Tian, Y. WO2017075583, 2017; Chem. Abstr. 2017, 166, 521976. 
20. Zhou, X.; Yu, L.; Feng, Y. CN102206189A, 2011; Chem. Abstr. 2011, 155, 510206.

21. Geigle, P.; Hartwig, J.; Larionov, E.; Baal, E. WO2020035548, 2020; Chem. Abstr. 2020, 172, 245460.

22. Fan, H.; Li, Y.; Shao, S.; Ren, X. CN106554322, 2017; Chem. Abstr. 2017, 166, 431903.

23. Laha, J. K.; Tummalapalli, K. S. S.; Gupta, A. Eur. J. Org. Chem. 2013, No. 36, 8330-8335. https://doi.org/10.1002/ejoc.201301091.

24. Flood, M. E.; Herbert, R. B.; Holliman, F. G. J. Chem. Soc. Perkin Trans. 1 1972, 622-626. https://doi.org/10.1039/p19720000622.

25. Holliman, F. G.; Jeffery, B. A.; Brocks, D. J. H. Tetrahedron 1963, 19, 1841-1848. https://doi.org/10.1016/S0040-4020(01)99258-0.

26. Emoto, T.; Kubosaki, N.; Yamagiwa, Y.; Kamikawa, T. Tetrahedron Lett. 2000, 41, 355-358. https://doi.org/10.1016/S0040-4039(99)02061-4.

27. Gottlieb, H. E.; Kotlyar, V.; Nudelman, A., J. Org. Chem. 1997, 62, 7512-7515. https://doi.org/10.1021/jo971176v

28. Lin-Vien, D.; Colthup, N. B.; Fateley, W. G.; Grasselli, J. G. The Handbook of Infrared and Raman Characteristic Frequencies of Organic Molecules; Academic Press: Boston, 1991. 